\title{
Evaluability Assessment of Indonesian Marine Conservation Areas for Management Effectiveness Evaluation
}

\author{
Arisetiarso Soemodinoto ${ }^{1 *}$ and Mirza Pedju² \\ 1 Program Kelautan, Yayasan Konservasi Alam Nusantara (YKAN) \\ Graha Iskandarsyah Lantai 3, Jalan Iskandarsyah Raya 66c Kebayoran Baru, Jakarta Selatan 12160, Indonesia \\ 2Freelance Consultant, 6/40 Lake Road, Narrow Neck, Auckland 0624, New Zealand \\ Email: a.soemodinoto@ykan.or.id
}

\begin{abstract}
The management effectiveness evaluation of marine conservation areas (MCAs) in Indonesia is often conducted assuming that they are likely to be evaluated periodically. However, for good and reliable results, it is recommended to perform the evaluability assessment prior to any evaluation to determine whether an MCA can be evaluated or not. This study aims to assess the evaluability of MCAs managed by the Ministry of Marine Affairs and Fisheries (MMAF) by reviewing their management plans and effectiveness evaluation tools. By employing a qualitative approach, this study found that (i) the management plans are not conceived to support an effective management of MCAs in the field or the evaluation of management effectiveness; and (ii) the current guidelines for evaluating MCA management effectiveness do not evaluate the expected achievements of management actions relative to biodiversity conservation goals and objectives. As a result, MCAs under MMAF direct supervision are not evaluable, and hence, the evaluations are pointless from a biodiversity conservation perspective. To address this discrepancy, it is recommended that the management effectiveness evaluation should only be applied to MCAs with an effectiveness-oriented management plan and should employ tools or guidelines that are devised to evaluate the achievement of MCA conservation goals and objectives.
\end{abstract}

Keywords: MPA, evaluation, effectiveness, policy, regulations

\section{Introduction}

As a country that has ratified the United Nations Convention of Biological Diversity (via Law $5 / 1994$ concerning the Ratification of the United Nations Convention of Biological Diversity), Indonesia is committed to achieving the coastal and marine objectives of the Aichi Biodiversity Target 11 (Soemodinoto et al., 2018). This commitment was demonstrated by the establishment of 197 marine conservation areas (MCAs) spanning a total area of 23.4 million hectares, which equates to around $7.1 \%$ of Indonesia's coastal and marine waters (Rusandi, 2020). However, the latest assessment of management effectiveness found that, by the end of the first quarter of 2020 , out of the 167 MCAs established by the Ministry of Marine Affairs and Fisheries (MMAF) and the provincial governments, only 24 (around 14\%) have achieved "minimally managed" status (Rusandi, 2020). While it is understood that the MMAF only initiated MCAs management effectiveness evaluations in 2012 (via Director General of Marine, Coasts, and Small Islands Decree 44/2012 concerning Technical Guidelines for Evaluating Management Effectiveness of Aquatic, Coasts, and Small Islands Conservation Area, hereafter DGMCSI Decree 44/2012), this rather low percentage of achievement deserves further examination in order to identify probable causes beyond insufficient human and funding resources for effective MCA management (Gill et al., 2017).

Recent developments in the field of evaluation recommend that any program, project, or activity should be subjected to evaluability assessment as a prerequisite for obtaining good or valid evaluation results (Davies, 2013). Evaluability, defined as "the extent to which an activity or a program can be evaluated in a reliable and credible fashion" (OECD, 2002) should be assessed "to ascertain whether its objectives are adequately defined and its results verifiable" (OECD, 2002). In practice, the evaluability assessment is carried out before the full evaluation is implemented. Based on this recommendation, the authors reviewed MCA management plans and effectiveness evaluation practices by the MMAF to identify gaps and opportunities for improving the evaluation exercises and their results. In so doing, the authors referred to the MCA management plans and the tools used for evaluating MCA management effectiveness in Indonesia. These aspects correspond to evaluability assessment issues such as program or 
project management intervention, effectiveness evaluation design and relevance, and the availability of data and information relevant to management actions in the field and effectiveness evaluation (Davies, 2013). This paper reports the review results and proposes several recommendations to improve both the effectiveness of MCA management and the management effectiveness evaluation processes in Indonesia in the future.

\section{Materials and Methods}

A qualitative approach was employed for collecting and analyzing data. All data were generated from publicly available official documents such as management plans and regulations (Rapley and Rees, 2018) and subjected to content analysis (Schreier, 2014). The management plans consulted included the management and zoning plans (hereafter MZPs) of 10 MCAs under the direct supervision of the MMAF (Table 1.) that are spread across Indonesia (Figure 1.). The authors used these particular documents because they were utilized by the provincial governments as a model for preparing the management and zoning plans of the provinciallevel MCAs. The aspects examined were the presence of (i) SMART (specific, measurable, attainable, realistic, time-bound) goals and objectives; (ii) conservation targets; (iii) direct and indirect threats to the targets; (iv) strategies to reduce or eliminate threats, including zoning; and ( $v$ ) monitoring plans (Thomas and Middleton, 2003; Pomeroy et al., 2005; Hockings et al., 2006; Conservation Measures Partnership, 2020). These aspects are widely considered relevant to the definition of management effectiveness, i.e., the degree to which management actions are achieving the goals and objectives of the protected area (Hockings et al., 2000; Pomeroy et al., 2005). The regulations consulted included the regulations on MCA management effectiveness evaluation technical guidelines (DGMCSI Decree 44/2012) which were later amended by the Director General of Marine Spatial Management Decree 28/2020 concerning Technical Guidelines for Evaluation of Conservation Areas Management Effectiveness (hereafter DGMSM Decree 28/2020), planning of MCA management and zoning (Minister of Marine Affairs and Fisheries Regulation 30/2010 concerning Aquatic Conservation Area Management and Zoning Plans, hereafter MMAF Ministerial Regulation 30/2010), and the description of MCAs (Government of Indonesia Regulation 60/2007 concerning the Conservation of Fish Resources, hereafter Government Regulation 60/2007; and Minister of Marine Affairs and Fisheries Regulation 17/2008 concerning Coastal and Small Island Conservation Areas, hereafter MMAF Ministerial Regulation 17/2008).

Table 1. List of 10 Marine Conservation Areas under the direct supervision of the MMAF, and ministerial decree establishing the management and zoning plan (MZP) for each MCA

\begin{tabular}{lll}
\hline \multicolumn{1}{c}{ Name and type MCA } & MZP legal recognition & \multicolumn{1}{c}{ Management unit } \\
\hline Anambas Islands Marine Recreation & MMAF Ministerial Decree 53/2014 & National Aquatic Conservation Area \\
Park (MRP; in Riau Islands Province) & & Sub-Office (Loka Kawasan Konservasi \\
& & Perairan Nasional or LKKPN) \\
& & Pekanbaru \\
Banda Sea MRP (in Maluku Province) & MMAF Ministerial Decree 58/2014 & National Aquatic Conservation Area \\
& & Office (Balai Kawasan Konservasi \\
& & Perairan Nasional or BKKPN) Kupang
\end{tabular}

Gili Matra MRP (in West Nusa Tenggara Province)

Kapoposang Islands MRP (in South Sulawesi Province)

Padaido Islands MRP (in Papua

Province)

Pieh Islands MRP (in West Sumatera Province)

Raja Ampat Islands Marine Nature

Reserve (MNR; in West Papua

Province)

Savu Sea Marine National Park (in East Nusa Tenggara Province)

Southeast Aru Islands MNR (in Maluku Province)

Western Waigeo Islands MNR (in West Papua Province)
MMAF Ministerial Decree 57/2014 BKKPN Kupang

MMAF Ministerial Decree 59/2014 BKKPN Kupang

MMAF Ministerial Decree 62/2014 BKKPN Kupang

MMAF Ministerial Decree 38/2014 LKKPN Pekanbaru

MMAF Ministerial Decree 63/2014 BKKPN Kupang

MMAF Ministerial Decree 06/2014 BKKPN Kupang

MMAF Ministerial Decree 64/2014 BKKPN Kupang

MMAF Ministerial Decree 60/2014 BKKPN Kupang 


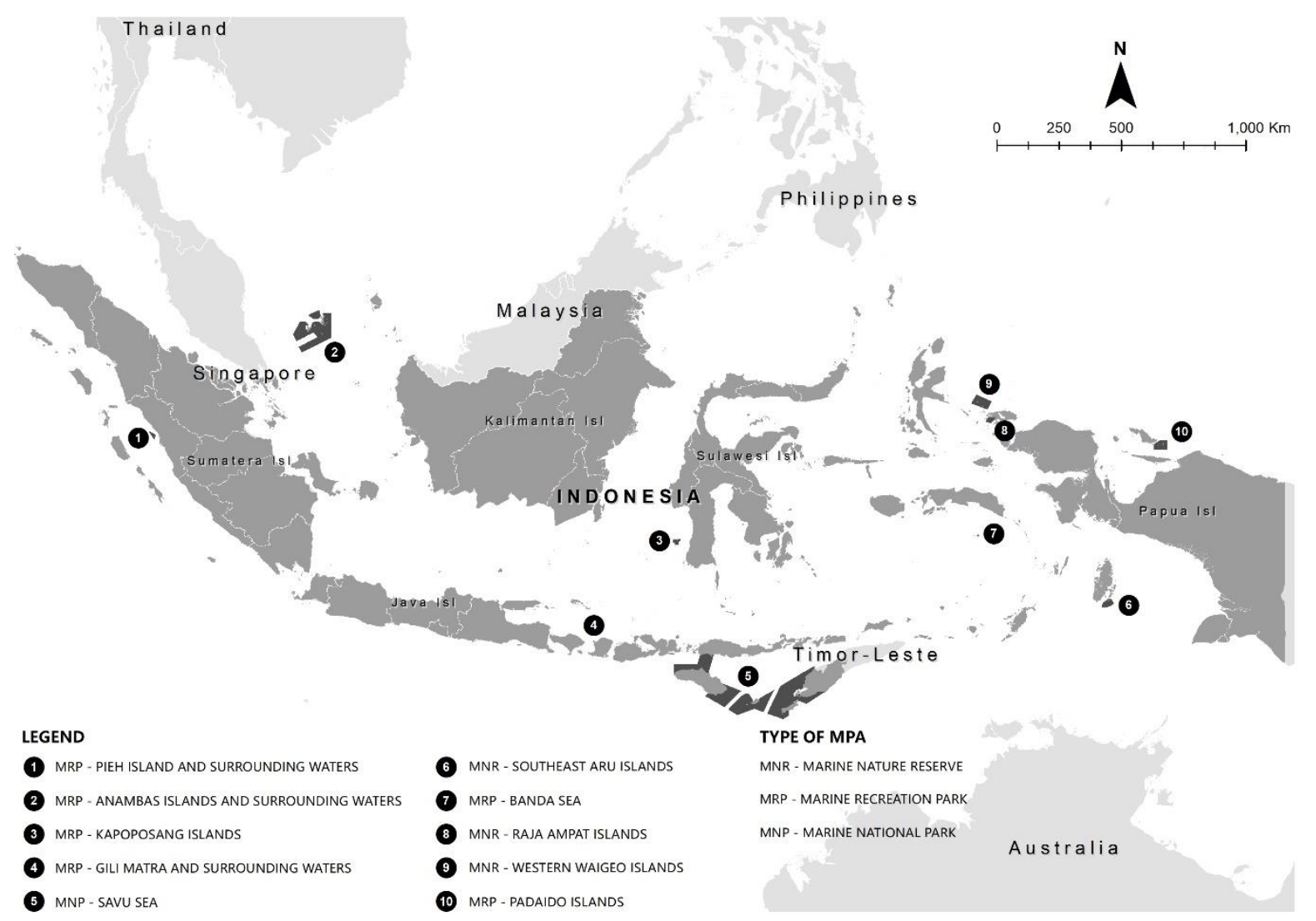

Figure 1. Locations of marine conservation areas managed by the Ministry of Marine Affairs and Fisheries across Indonesia

\section{Results and Discussion}

\section{MCA management plans}

The preparation of the MZPs for MCAs under the jurisdiction of the MMAF and the provincial government is guided by a ministerial regulation formulated for that specific purpose (MMAF Ministerial Regulation 30/2010). Reviews of the MZPs of 10 MCAs under the direct supervision of the MMAF indicate that the structure and content of all the documents are similar, following the prescribed content presented in Table 2.

However, upon further inspection, it was found that none of the MZPs were equipped with important attributes to support the effective management of an MCA in the field (Table 3.). First, with the exception of the Gili Matra Marine Recreation Park (MRP) MZP, the management goals and objectives stated in the MZPs are too broad, ambitious, and not focused on the biophysical outcomes, and hence difficult to appraise. However, these goals and objectives are generally seen as the basis for evaluating management effectiveness (Hockings et al., 2000, 2006; Pomeroy et al., 2005). The goals and objectives do not employ the SMART formula recommended by the Conservation Measures Partnership (2020) and Thomas and Middleton (2003) due to the lack of prerequisite materials such as clear statements of the following: (i) conservation targets; (ii) direct and indirect threats to the targets; and (iii) strategies to reduce or eliminate threats. These materials are essential for rigorous situational analysis to formulate strategy-linked management goals and objectives (Conservation Measures Partnership, 2020).

Second, the zoning is not linked to management strategies and actions. Each zone has been provided with a list of rules (i.e. for allowable, allowable with permission, and not allowable activities) but there are no management objectives or biological indicators. Zones are established to reconcile conflicting activities in and around an MCA and to ensure that human activities do not negatively impact the biological features being protected or conserved (Kelleher, 1999; Salm et al., 2000; Thomas and Middleton, 2003; Day et al., 2015). Without management objectives and biological indicators, it would be impossible to implement management actions and measure their conservation outcomes in each zone, not to mention the periodic evaluation of zoning effectiveness (Kelleher, 1999). 
Table 2. The prescribed content of an MCA management and zoning plan (MZP) according to section (9) of Article 31 of MMAF Ministerial Regulation 30/2010

\begin{tabular}{|c|c|}
\hline Chapter & Sub-chapter and content \\
\hline Introduction & $\begin{array}{l}\text { - Background } \\
\text { - Objective of management plan making } \\
\text { - Scope of management plan making }\end{array}$ \\
\hline $\begin{array}{l}\text { Ecological, economic, and social-cultural } \\
\text { potential of the conservation area, and } \\
\text { management problems }\end{array}$ & $\begin{array}{l}\text { - Ecological potential } \\
\text { - Economic potential } \\
\text { - Social-cultural potential } \\
\text { - Management problems }\end{array}$ \\
\hline Zoning & - Corresponds to section (6) of Article 31 which describes MCA zoning \\
\hline MCA management policy & $\begin{array}{l}\text { - Corresponds to section (2) of Article } 5 \text { which covers (a) vision and mission; } \\
\text { (b) management goals and objectives; and (c) management strategies }\end{array}$ \\
\hline MCA management strategy & $\begin{array}{l}\text { - Corresponds to Article } 6 \text { which specifies three management strategies, i.e. } \\
\text { (1) institutional strengthening, (2) strengthening of MCA resource } \\
\text { management, and (3) social, economic, and cultural strengthening }\end{array}$ \\
\hline MCA management programs & $\begin{array}{l}\text { - Corresponds to program options which are specified in sections (2), (3), and } \\
\text { (4) of Article } 7 \text { as the elaboration of three strategies specified in Article } 6\end{array}$ \\
\hline MCA management work plan & $\begin{array}{l}\text { - Long-term (20 years) work plan corresponding to Article } 5 \\
\text { - Medium-term (5 years) work plan corresponding to Article } 7 \\
\text { - Annual work plan corresponding to Article } 8\end{array}$ \\
\hline
\end{tabular}

Third, none of the MZPs have a monitoring plan. Monitoring of management actions and results is fundamental for effectiveness evaluation because only through this can the decision on whether or not the management strategy is working be made and the conservation outcomes be measured and tracked down (Hockings et al., 2000, 2006; Addison et al., 2017, 2018; Conservation Measures Partnership, 2020; Dunham et al., 2020).

These findings indicate that none of the MZPs were prepared to support effective management of the MCA in the field or to enable the MCA to be evaluated for management effectiveness. This suggests that none of the MCAs are evaluable or eligible to be evaluated. Since the importance of a management plan in guiding the implementation of actions by the MCA management unit (Kelleher, 1999; Salm et al., 2000; Thomas and Middleton, 2003; Day et al., 2015) for effective management (Alvarez-Fernandez et al., 2020a; 2020b) is recognized, it is crucial to incorporate all the aforementioned attributes into the management plans.

A management plan is core to marine protected area management (Kelleher, 1999; Salm et al., 2000; Thomas and Middleton, 2003; Day et al., 2015; Alvarez-Fernandez et al., 2020a, 2020b); hence, to accommodate effective management and the evaluation of management effectiveness, the plan must be prepared from the beginning to incorporate certain attributes for management effectiveness practices and evaluation. The attributes include (i) conservation targets, (ii) direct and indirect threats to the targets, and (iii) strategies to tackle threats (Conservation Measures Partnership, 2020).
For all MCAs under the direct supervision of the MMAF, it is highly recommended that the MZPs be revised by incorporating the aforementioned attributes and rigorous situational analysis to identify the most relevant problems, formulate the problem statement, and establish the SMART biodiversity conservation goals and objectives.

To guide a fair evaluation of management effectiveness in the future, the authors propose a working definition of management effectiveness for Indonesian MCAs: "the degree to which management actions achieve the biodiversity protection, conservation and sustainable use goals and objectives of a marine conservation area." This definition is more explicit than that outlined in the technical guidelines (DGMCSI decree 44/2012) and the widely accepted definition (Pomeroy et al., 2005; Hockings et al., 2006). It is strongly suggested that the management actions' goals and objectives to be evaluated should be the conservation goals and objectives of biodiversity protection, conservation, and sustainable use. It is about time that Indonesia focuses on biodiversity outcomes to indicate MCA management effectiveness. If necessary, the socioeconomic impacts of MCA biodiversity outcomes could also be studied to demonstrate the importance of biodiversity to support economic development (Kelleher, 1999; Salm et al., 2000; Fox et al., 2014; Day et al., 2015; Rosales, 2018).

These objectives should be expanded to further cover every established zone along with the relevant biological indicators. With everything in place, monitoring plans can be created to track down management actions with respect to the protection, conservation, and sustainable use of biodiversity in the MCA and later be used for management 
effectiveness evaluation. Besides conventional biological monitoring, human pressures and threats should be monitored (Dunham et al., 2020). Finally, the revised MZPs must openly state, in the executive summary, the conservation goals and objectives to be achieved over a specific period in order to make them eligible and evaluable for management effectiveness evaluation.

\section{Management effectiveness evaluation guideline}

The management effectiveness evaluation of MPAs under the jurisdictions of MMAF and the provincial governments was originally carried out periodically by employing the Marine Conservation Area Management Effectiveness Evaluation (MCAMEE) technical guidelines enacted in 2012 (DGMCSI Decree 44/2012) before being amended by new technical guidelines under a regulation enacted in 2020 (DGMSM Decree 28/2020).

The old guidelines employed a scorecard with five management levels represented by 17 criteria and 74 questions (Table 4.), and their inception was influenced by the frameworks developed by White et al. (2006) and Carter et al. (2011). In the old guidelines, management effectiveness was defined as "the level or degree to which management of a conservation area has had a positive impact on the area's biophysical resources and on the socioeconomic and cultural aspects of the local community, which contributes to improving management performance" (DGMCSI Decree 44/2012, page 6). The management level represents the evolution of an MCA from being reserved and designated to fully managed, producing positive impacts for stakeholders, especially local communities and fishers. The evaluation results in percentages which are presented as a histogram, reflecting the MCA management "achievement" and hence management effectiveness. It was assumed that the higher percentage at a higher level, the higher the management effectiveness.

The old guidelines can be considered weak because they evaluate the achievements of less relevant non-management action attributes such as the conservation area's reservation and establishment processes; the development of human resources, infrastructure and facilities; and sustainable financing. The authors believe that the activities required to achieve these attributes have distracted the management units from carrying out their primary responsibilities of managing the conservation area and the human activities which pose threats to biodiversity. In order to support full and meaningful evaluation, these non-management action issues must first be addressed before the management effectiveness evaluation is carried out.

The new guidelines differ profoundly from the old guidelines because they now employ a modified framework based on the evaluation cycle (Hockings et al., 2000, 2006), i.e., they use input, process, output, and outcome criteria with associated indicators and weighed scores (Table 5.). Under these new guidelines, the management levels are differentiated into three levels and a ceiling percentage has been determined beforehand for each level (Table 6.). However, no definition of management effectiveness is provided.

Despite profound changes, problems remain. First, the new technical guidelines do not measure and evaluate the achievement of management actions and conservation goals and objectives straighforwardly, and there is no framework provided in order to guide the relation between management outputs and outcomes. In the authors' opinion, some of the outcomes are misplaced. Since the goals and objectives of MCAs in Indonesia are to protect, conserve, and use biodiversity sustainably, it is logical to put only biological indicators for the outcomes. Second, the new technical guidelines keep using percentages to indicate the "achievements" of effective management; such qualitative results are inconclusive and do not reflect anything close to the achievement of management actions, let alone conservation goals and objectives (Addison et al., 2017).

These findings suggest that, over the years, the evaluation of management effectiveness has not been based on the problems affecting the biodiversity (or living resources such as fishes) being protected and conserved in the MCA. In the field of evaluation, one important aspect to evaluate is the relevance and effectiveness of the interventions, both in terms of design and implementation, to address the identified problems (OECD, 2002; Davies, 2013); in other words, the management actions must be relevant and effective for tackling the threats to biodiversity from human activities (Conservation Measures Partnership, 2020). One aspect in particular that should be evaluated with respect to management effectiveness is how the designed interventions (i.e., management actions) perform against the problems (threats to biodiversity from human activities), rather than concentrating on the issues of human resources, facilities, infrastructure, and funding behind the interventions. Threat reduction or elimination (Conservation Measures Partnership, 2020; Dunham et al., 2020) should be the main thrust or characteristic of an effectiveness-oriented MCA management plan and should act as the basis for evaluation. 
ILMU KELAUTAN: Indonesian Journal of Marine Sciences March 2022 Vol 27(1):61-72

Table 3. Components of MCA management plans examined for this study

\begin{tabular}{|c|c|c|c|c|c|}
\hline \multirow{2}{*}{$\begin{array}{l}\text { Management } \\
\text { plan } \\
\text { components }\end{array}$} & \multicolumn{5}{|c|}{ Name and Type of Marine Conservation Area (MCA) } \\
\hline & Anambas MRP & Banda Sea MRP & Gili Matra MRP & $\begin{array}{l}\text { Kapoposang } \\
\text { Islands MRP }\end{array}$ & $\begin{array}{c}\text { Padaido Islands } \\
\text { MRP }\end{array}$ \\
\hline $\begin{array}{l}\text { Management } \\
\text { goal(s) }\end{array}$ & $\begin{array}{l}\text { - Reducing to } \\
\text { eliminating } \\
\text { threats to the } \\
\text { MCA } \\
\text { - Facilitating } \\
\text { recovery of } \\
\text { ecosystems in } \\
\text { the MCA } \\
\text { - Regulating MCA } \\
\text { usefollowing the } \\
\text { zoning plan } \\
\text { - Managing MCA } \\
\text { resources and } \\
\text { environment in a } \\
\text { sustainable } \\
\text { fashion } \\
\text { - Facilitating } \\
\text { utilization of the } \\
\text { marine tourism } \\
\text { potential and } \\
\text { sustainable } \\
\text { fisheries for } \\
\text { empowerment of } \\
\text { local } \\
\text { communities } \\
\text { - Improving the } \\
\text { welfare of } \\
\text { communities } \\
\text { living in the } \\
\text { surrounding area } \\
\text { - Achieving MCA } \\
\text { management } \\
\text { effectiveness }\end{array}$ & $\begin{array}{l}\text { - Implementing } \\
\text { management } \\
\text { efforts to realize } \\
\text { Banda Sea MRP } \\
\text { as national } \\
\text { recreation } \\
\text { destination } \\
\text { - Maintaining } \\
\text { marine } \\
\text { biodiversity and } \\
\text { local wisdom for } \\
\text { the welfare of } \\
\text { local } \\
\text { communities }\end{array}$ & $\begin{array}{l}\text { This MCA does not } \\
\text { differentiate goals and } \\
\text { objectives: } \\
\text { - In 2012, the average } \\
\text { of hard coral coverage } \\
\text { in three islets was } \\
24 \% \text {. It is expected } \\
\text { that in } 2019 \text { the } \\
\text { percentage would be } \\
27 \% \text {, in } 202430 \% \text {, in } \\
202933 \% \text {, and in } \\
203436 \% \\
\text { - In } 2012 \text {, the average } \\
\text { of reef fish abundance } \\
\text { in three islets was } \\
29,299 \text { fish/Ha. It is } \\
\text { expected that in } 2019 \\
\text { the abundance would } \\
\text { increase to } 30,178 \\
\text { fish/Ha, in } 2024 \\
31,083 \text { fish/Ha, in } \\
202932,015 \text { fish/Ha, } \\
\text { and in 2034 } 32,976 \\
\text { fish/Ha } \\
\text { In } 2012 \text {, the average } \\
\text { of reef fish biomass in } \\
\text { three islets was } 557 \\
\mathrm{~kg} / \mathrm{Ha} \text {. It is expected } \\
\text { that in } 2019 \text { the } \\
\text { biomass would } \\
\text { increase to } 574 \\
\mathrm{~kg} / \mathrm{Ha} \text {, in } 2024591 \\
\mathrm{~kg} / \mathrm{Ha} \text {, in } 2029609\end{array}$ & $\begin{array}{l}\text { This MCA does not } \\
\text { differentiate goals } \\
\text { and objectives: } \\
\text { - To protect and } \\
\text { conserve } \\
\text { fisheries } \\
\text { resources and } \\
\text { marine } \\
\text { ecosystems in } \\
\text { the Kapoposang } \\
\text { Islands Marine } \\
\text { Recreation Park } \\
\text { to ensure the } \\
\text { future } \\
\text { sustainability of } \\
\text { ecological } \\
\text { functions } \\
\text { - To achieve } \\
\text { sustainable use } \\
\text { of fisheries } \\
\text { resources, } \\
\text { coastal and } \\
\text { marine } \\
\text { resources, and } \\
\text { environmental } \\
\text { services } \\
\text { - To increase the } \\
\text { welfare of local } \\
\text { communities in } \\
\text { the McA and the } \\
\text { surrounding area }\end{array}$ & $\begin{array}{l}\text { - To implement } \\
\text { management } \\
\text { efforts in } \\
\text { order to } \\
\text { realize } \\
\text { Padaido } \\
\text { Islands Marine } \\
\text { Recreation } \\
\text { Park as a } \\
\text { reputable park } \\
\text { which is } \\
\text { beautiful, } \\
\text { sustainable, } \\
\text { and improves } \\
\text { the welfare of } \\
\text { local } \\
\text { communities }\end{array}$ \\
\hline $\begin{array}{l}\text { Management } \\
\text { objectives }\end{array}$ & $\begin{array}{l}\text { - Improve } \\
\text { institutional } \\
\text { capacity of } \\
\text { management } \\
\text { unit and } \\
\text { stakeholders in } \\
\text { managing the } \\
\text { area } \\
\text { - Threats toward } \\
\text { the area are } \\
\text { reduced or } \\
\text { eliminated } \\
\text { - Damaged } \\
\text { ecosystems are } \\
\text { recovered, and } \\
\text { threatened } \\
\text { ecosystems and } \\
\text { species are } \\
\text { protected } \\
\text { - McA utilization } \\
\text { in-line with the } \\
\text { established } \\
\text { zoning plan and } \\
\text { based on marine } \\
\text { tourism is } \\
\text { achieved }\end{array}$ & $\begin{array}{l}\text { - Banda Sea MRP } \\
\text { management } \\
\text { systems } \\
\text { implemented } \\
\text { which embrace } \\
\text { ecosystem, } \\
\text { precautionary } \\
\text { principles, } \\
\text { integrative, } \\
\text { adaptive and } \\
\text { participative } \\
\text { approaches, } \\
\text { - Marine } \\
\text { resources in } \\
\text { Banda Sea MRP } \\
\text { utilized } \\
\text { optimally and in } \\
\text { sustainable } \\
\text { fashion } \\
\text { - Local wisdom } \\
\text { practices } \\
\text { implemented to } \\
\text { support the } \\
\text { management of } \\
\text { Banda Sea MRP } \\
\text { and provide }\end{array}$ & $\begin{array}{l}\mathrm{kg} / \mathrm{Ha} \text {, and in } 2034 \\
627 \mathrm{~kg} / \mathrm{Ha} \\
\text { - In } 2012 \text {, local } \\
\text { community } \\
\text { compliance with no- } \\
\text { take zones (core and } \\
\text { utilization zones) was } \\
96.1 \% \text {. It is expected } \\
\text { that this level will be } \\
\text { increased or } \\
\text { maintained throughout } \\
\text { the monitoring period } \\
\text { - In } 2012 \text {, local } \\
\text { community support } \\
\text { toward MCA } \\
\text { management was } \\
54 \% \text {. It is expected } \\
\text { this level will be } \\
\text { increased or } \\
\text { maintained throughout } \\
\text { the monitoring period } \\
\text { - In } 2012 \text {, the level of } \\
\text { local community } \\
\text { participation in MCA } \\
\text { management was } \\
26 \% \text {. It is expected } \\
\text { that this level will be }\end{array}$ & & $\begin{array}{l}\text { - To establish } \\
\text { an } \\
\text { effectiveMCA } \\
\text { management } \\
\text { institutional } \\
\text { system to } \\
\text { ensure } \\
\text { integrated and } \\
\text { participative } \\
\text { area } \\
\text { surveillance } \\
\text { - To maintain } \\
\text { the quality of } \\
\text { the MCA } \\
\text { resources and } \\
\text { ecosystems to } \\
\text { ensure } \\
\text { sustainable } \\
\text { use } \\
\text { - To increase } \\
\text { local } \\
\text { community } \\
\text { welfare and } \\
\text { participation } \\
\text { in MCA } \\
\text { management }\end{array}$ \\
\hline
\end{tabular}




\begin{tabular}{|c|c|c|c|c|c|}
\hline & $\begin{array}{l}\text { - Activities in the } \\
\text { marine } \\
\text { recreation park } \\
\text { are carried out in } \\
\text { sustainable } \\
\text { fashion and } \\
\text { involve local } \\
\text { stakeholders } \\
\text { - Integrated and } \\
\text { sustainable } \\
\text { management of } \\
\text { the MCA based } \\
\text { upon marine } \\
\text { tourism is } \\
\text { achieved } \\
\text { - Programs and } \\
\text { activities to } \\
\text { improve local } \\
\text { communities in } \\
\text { the surrounding } \\
\text { area are } \\
\text { implemented }\end{array}$ & $\begin{array}{l}\text { economic } \\
\text { benefits to local } \\
\text { communities }\end{array}$ & $\begin{array}{l}\text { increased or } \\
\text { maintained throughout } \\
\text { the monitoring period } \\
\text { - By 2014: governance, } \\
\text { ecological and } \\
\text { community social- } \\
\text { economic indicators } \\
\text { for management } \\
\text { decided } \\
\text { - By 2014: partnership } \\
\text { mechanisms available } \\
\text { for MCA management } \\
\text { By } 2015 \text { : standard } \\
\text { operational } \\
\text { procedures available } \\
\text { for management } \\
\text { (institutional } \\
\text { strengthening, joint } \\
\text { patrols, natural } \\
\text { resource } \\
\text { management, social, } \\
\text { economic \& cultural } \\
\text { strengthening, } \\
\text { research \& education, } \\
\text { implementation of } \\
\text { marine nature tourism, } \\
\text { mariculture, capture } \\
\text { fisheries, and law } \\
\text { enforcement) } \\
\text { - By } 2015, \text { sustainable } \\
\text { financing mechanisms } \\
\text { available for MCA } \\
\text { management } \\
\text { - By } 2017, \text { MCA } \\
\text { surveillance carried } \\
\text { out via } 20 \text { patrols by } \\
\text { the management unit } \\
\text { in collaboration with } \\
\text { local communities } \\
\text { - Increase in Catch per } \\
\text { unit effort (kg/trip) in } \\
\text { the sustainable } \\
\text { fisheries zone in every } \\
\text { monitoring period }\end{array}$ & & \\
\hline Zoning & $\begin{array}{l}\text { The park has: } \\
\text { - Core zone (with } \\
\text { list of allowable } \\
\text { and not } \\
\text { allowable } \\
\text { activities), but no } \\
\text { management } \\
\text { objectives and } \\
\text { biological } \\
\text { indicators were } \\
\text { provided } \\
\text { - Sustainable } \\
\text { fisheries zone } \\
\text { (with list of } \\
\text { allowable and } \\
\text { not allowable } \\
\text { activities), but no } \\
\text { management } \\
\text { objectives and } \\
\text { biological }\end{array}$ & $\begin{array}{l}\text { The park has: } \\
\text { - Core zone (with } \\
\text { list of allowable } \\
\text { and not } \\
\text { allowable } \\
\text { activities), but } \\
\text { no } \\
\text { management } \\
\text { objectives and } \\
\text { biological } \\
\text { indicators were } \\
\text { provided } \\
\text { - Sustainable } \\
\text { fisheries zone, } \\
\text { including a sub- } \\
\text { zone for } \\
\text { sustainable } \\
\text { mariculture } \\
\text { (with list of } \\
\text { allowable and } \\
\text { not allowable }\end{array}$ & $\begin{array}{l}\text { The park has: } \\
\text { - Core zone (with list of } \\
\text { allowable with permit } \\
\text { and not allowable } \\
\text { activities), but no } \\
\text { management } \\
\text { objectives and } \\
\text { biological indicators } \\
\text { were provided } \\
\text { - Sustainable fisheries } \\
\text { zone, including a sub- } \\
\text { zone for sustainable } \\
\text { reef fisheries (with list } \\
\text { of allowable, allowable } \\
\text { with permit, and not } \\
\text { allowable activities), } \\
\text { but no management } \\
\text { objectives and } \\
\text { biological indicators } \\
\text { were provided }\end{array}$ & $\begin{array}{l}\text { The park has: } \\
\text { - Core zone (with } \\
\text { list of allowable } \\
\text { and not } \\
\text { allowable } \\
\text { activities), but no } \\
\text { management } \\
\text { objectives and } \\
\text { biological } \\
\text { indicators were } \\
\text { provided } \\
\text { - Sustainable } \\
\text { fisheries zone, } \\
\text { including sub- } \\
\text { zones for } \\
\text { sustainable } \\
\text { traditional } \\
\text { fisheries (with list } \\
\text { of allowable and } \\
\text { not allwoable } \\
\text { activities), but no }\end{array}$ & $\begin{array}{l}\text { The park has: } \\
\text { - Core zone } \\
\text { (with list of } \\
\text { allowable and } \\
\text { not allowable } \\
\text { activities), but } \\
\text { no } \\
\text { management } \\
\text { objectives and } \\
\text { biological } \\
\text { indicators } \\
\text { were provided } \\
\text { - Sustainable } \\
\text { fisheries zone, } \\
\text { including sub- } \\
\text { zones for } \\
\text { sustainable } \\
\text { traditional } \\
\text { fisheries (with } \\
\text { list of } \\
\text { allowable and }\end{array}$ \\
\hline
\end{tabular}




\begin{tabular}{|c|c|c|c|c|c|}
\hline & $\begin{array}{l}\text { indicators were } \\
\text { provided } \\
\text { - General } \\
\text { utilization zone } \\
\text { (with list of } \\
\text { allowable and } \\
\text { not allowable } \\
\text { activities), but no } \\
\text { management } \\
\text { objectives and } \\
\text { biological } \\
\text { indicators were } \\
\text { provided } \\
\text { - Other zone, } \\
\text { particularly for } \\
\text { rehabilitation } \\
\text { (with list of } \\
\text { allowable and } \\
\text { not allowable } \\
\text { activities), but no } \\
\text { management } \\
\text { objectives and } \\
\text { biological } \\
\text { indicators were } \\
\text { provided }\end{array}$ & $\begin{array}{l}\text { activities), but } \\
\text { no } \\
\text { management } \\
\text { objectives and } \\
\text { biological } \\
\text { indicators were } \\
\text { provided } \\
\text { - General } \\
\text { utilization zone } \\
\text { (with list of } \\
\text { allowable and } \\
\text { not allowable } \\
\text { activities), but } \\
\text { no } \\
\text { management } \\
\text { objectives and } \\
\text { biological } \\
\text { indicators were } \\
\text { provided } \\
\text { - Rehabilitation } \\
\text { zone (with list of } \\
\text { allowable and } \\
\text { not allowable } \\
\text { activities), but } \\
\text { no } \\
\text { management } \\
\text { objectives and } \\
\text { biological } \\
\text { indicators were } \\
\text { provided }\end{array}$ & $\begin{array}{l}\text { - Utilization zone (with } \\
\text { list of allowable, } \\
\text { allowable with permit, } \\
\text { and not allowable } \\
\text { activities), but no } \\
\text { management } \\
\text { objectives and } \\
\text { biological indicators } \\
\text { were provided } \\
\text { - Other zone which } \\
\text { consists of } \\
\text { rehabilitation, } \\
\text { protection and port } \\
\text { sub-zones (with list of } \\
\text { allowable, allowable } \\
\text { with permit, and not } \\
\text { allowable activities), } \\
\text { but no management } \\
\text { objectives and } \\
\text { biological indicators } \\
\text { were provided }\end{array}$ & $\begin{array}{l}\text { management } \\
\text { objectives and } \\
\text { biological } \\
\text { indicators were } \\
\text { provided } \\
\text { - Utilization zone } \\
\text { (with list of } \\
\text { allowable and } \\
\text { not allowable } \\
\text { activities), but no } \\
\text { management } \\
\text { objectives and } \\
\text { biological } \\
\text { indicators were } \\
\text { provided } \\
\text { - Other zone for } \\
\text { rehabilitation } \\
\text { (with list of } \\
\text { allowable and } \\
\text { not allowable } \\
\text { activities), but no } \\
\text { management } \\
\text { objectives and } \\
\text { biological } \\
\text { indicators were } \\
\text { provided }\end{array}$ & $\begin{array}{l}\text { not allwoable } \\
\text { activities), but } \\
\text { no } \\
\text { management } \\
\text { objectives and } \\
\text { biological } \\
\text { indicators } \\
\text { were provided } \\
\text { - Utilization } \\
\text { zone (with list } \\
\text { of allowable } \\
\text { and not } \\
\text { allowable } \\
\text { activities), but } \\
\text { no } \\
\text { management } \\
\text { objectives and } \\
\text { biological } \\
\text { indicators } \\
\text { were provided } \\
\text { Other zone } \\
\text { which consists } \\
\text { of } \\
\text { rehabilitation, } \\
\text { protection and } \\
\text { port sub-zones } \\
\text { (with list of } \\
\text { allowable, } \\
\text { allowable with } \\
\text { permit, and } \\
\text { not allowable } \\
\text { activities), but } \\
\text { no } \\
\text { management } \\
\text { objectives and } \\
\text { biological } \\
\text { indicators } \\
\text { were provided }\end{array}$ \\
\hline $\begin{array}{l}\text { Monitoring } \\
\text { plan }\end{array}$ & - Not available & - Not available & - Not available & - Not available & - Not available \\
\hline $\begin{array}{l}\text { Conservation } \\
\text { targets }\end{array}$ & $\begin{array}{l}\text { - Not specifically } \\
\text { identified and } \\
\text { linked to threats }\end{array}$ & $\begin{array}{l}\text { - Not specifically } \\
\text { identified and } \\
\text { linked to } \\
\text { threats }\end{array}$ & $\begin{array}{l}\text { - Not specifically } \\
\text { identified and linked to } \\
\text { threats }\end{array}$ & $\begin{array}{l}\text { - Not specifically } \\
\text { identified and } \\
\text { linked to threats }\end{array}$ & $\begin{array}{l}\text { Not } \\
\text { specifically } \\
\text { identified and } \\
\text { linked to } \\
\text { threats } \\
\end{array}$ \\
\hline $\begin{array}{l}\text { Threats } \\
\text { (direct and } \\
\text { indirect) }\end{array}$ & $\begin{array}{l}\text { - Not specifically } \\
\text { identified and } \\
\text { linked to } \\
\text { conservation } \\
\text { targets }\end{array}$ & $\begin{array}{l}\text { - Not specifically } \\
\text { identified and } \\
\text { linked to } \\
\text { conservation } \\
\text { targets }\end{array}$ & $\begin{array}{l}\text { - Not specifically } \\
\text { identified and linked to } \\
\text { conservation targets }\end{array}$ & $\begin{array}{l}\text { - Not specifically } \\
\text { identified and } \\
\text { linked to } \\
\text { conservation } \\
\text { targets }\end{array}$ & $\begin{array}{l}\text { - Not } \\
\text { specifically } \\
\text { identified and } \\
\text { linked to } \\
\text { conservation } \\
\text { targets }\end{array}$ \\
\hline Strategies & $\begin{array}{l}\text { Follow strategies } \\
\text { prescribed in } \\
\text { Article } 6 \text { of } \\
\text { MMAF Ministerial } \\
\text { Regulation } \\
30 / 2010, \text { and } \\
\text { no clear link with } \\
\text { threats and } \\
\text { conservation } \\
\text { targets }\end{array}$ & $\begin{array}{l}\text { - Follow } \\
\text { strategies } \\
\text { prescribed in } \\
\text { Article } 6 \text { of } \\
\text { MMAF } \\
\text { Ministerial } \\
\text { Regulation } \\
\text { 30/2010, and } \\
\text { no clear link } \\
\text { with threats and } \\
\text { conservation } \\
\text { targets }\end{array}$ & $\begin{array}{l}\text { Follow strategies } \\
\text { prescribed in Article } 6 \\
\text { of MMAF Ministerial } \\
\text { Regulation } 30 / 2010 \text {, } \\
\text { and no clear link with } \\
\text { threats and } \\
\text { conservation targets }\end{array}$ & $\begin{array}{l}\text { - Follow strategies } \\
\text { prescribed in } \\
\text { Article } 6 \text { of } \\
\text { MMAF Ministerial } \\
\text { Regulation } \\
30 / 2010, \text { and no } \\
\text { clear link with } \\
\text { threats and } \\
\text { conservation } \\
\text { targets }\end{array}$ & $\begin{array}{l}\text { - Follow } \\
\text { strategies } \\
\text { prescribed in } \\
\text { Article } 6 \text { of } \\
\text { MMAF } \\
\text { Ministerial } \\
\text { Regulation } \\
30 / 2010 \text {, and } \\
\text { no clear link } \\
\text { with threats } \\
\text { and } \\
\text { conservation } \\
\text { targets } \\
\end{array}$ \\
\hline
\end{tabular}


ILMU KELAUTAN: Indonesian Journal of Marine Sciences March 2022 Vol 27(1):61-72

Table 4. Management level and criteria for evaluating management effectiveness of marine conservation areas in Indonesia according to the technical guideline 2012 (DGMCSI Decree 44/2012)

\begin{tabular}{|c|c|c|}
\hline & Level, assigned color \& naming & Criteria (number of questions) \\
\hline \multirow{3}{*}{$\begin{array}{l}(1) \\
\text { Red }\end{array}$} & The conservation area is initiated & Initiative proposal (2) \\
\hline & & Area identification \& inventory (5) \\
\hline & & 3. Reservation of conservation area (1) \\
\hline \multirow{4}{*}{$\begin{array}{l}(2) \\
\text { Yellow }\end{array}$} & The conservation area is established & 4. $\quad$ Management organizational unit \& personnel (4) \\
\hline & & 5. Management plan and zoning (2) \\
\hline & & $\begin{array}{l}\text { 6. Facilities \& infrastructure to support management } \\
\text { (4) }\end{array}$ \\
\hline & & 7. Management funding support (1) \\
\hline \multirow[t]{6}{*}{$\begin{array}{l}\text { (3) } \\
\text { Green }\end{array}$} & $\begin{array}{l}\text { The conservation area is minimally } \\
\text { managed }\end{array}$ & $\begin{array}{l}\text { 4. Management organizational unit \& personnel (3) } \\
\text { 5. Management and zoning plans (2) }\end{array}$ \\
\hline & & $\begin{array}{l}\text { 6. Facilities \& infrastructure to support management } \\
\text { (3) }\end{array}$ \\
\hline & & 8. Approval of management and zoning plans (2) \\
\hline & & $\begin{array}{l}\text { 9. Management standard operating procedures/SOPs } \\
\text { (3) }\end{array}$ \\
\hline & & $\begin{array}{l}\text { 10. Implementation of the management plan and zoning } \\
\text { (6) }\end{array}$ \\
\hline & & 11. Designation of the conservation area (2) \\
\hline \multirow{9}{*}{$\begin{array}{c}\text { (4) } \\
\text { Blue }\end{array}$} & The conservation area is optimally & 4. Management organizational unit \& personnel (1) \\
\hline & managed & $\begin{array}{l}\text { 6. Facilities \& infrastructure to support management } \\
\text { (1) }\end{array}$ \\
\hline & & 7. Management funding support (1) \\
\hline & & 9. Management SOPs (4) \\
\hline & & 11. Socialization of marine conservation area (1) \\
\hline & & 12. Conservation area boundary marking (1) \\
\hline & & 13. Institutionalization (7) \\
\hline & & 14. Area resources management (4) \\
\hline & & 15. Social, economic \& cultural management (8) \\
\hline \multirow{3}{*}{$\begin{array}{l}(5) \\
\text { Gold }\end{array}$} & Self-reliant conservation area & 13. Institutionalization (1) \\
\hline & & 16. Improving community welfare (4) \\
\hline & & 17. Sustainable financing (1) \\
\hline
\end{tabular}

Notes: words in italics indicate repeated criteria from the previous level

Table 5. Criteria and indicators for evaluating MCA management effectiveness according to MCAME technical guidelines 2020 (DGMSM Decree 28/2020, page 14)

\begin{tabular}{ll}
\hline Criteria & Indicators \\
\hline Inputs & - Context: status of conservation area (and category) \\
- Planning: zoning plan \\
- Planning: management plan \\
- Human resources \\
- Budget (funding support) \\
- (Management) infrastructure and facilities \\
\hline - Standard operational procedures for management \\
- Surveillance \\
- Outreach \\
- Partnership \\
- Monitoring of area resources \\
- Management of infrastructure and facilities \\
- Permitting \\
- Community empowerment \\
- Controlled utilization (of the conservation area) \\
- Threats (reduction) \\
- Compliance level (by resource users/ area visitors) \\
- Community knowledge (of conservation area) \\
- Community empowerment \\
- Data and information \\
\hline - Condition of conservation targets \\
- Condition of the core zone \\
- Condition of social-economic \\
- Community participation
\end{tabular}


ILMU KELAUTAN: Indonesian Journal of Marine Sciences March 2022 Vol 27(1):61-72

Table 6. Status of management effectiveness evaluation of an MCA according to MCAME technical guidelines 2020 (DGMSM Decree 28/2020, page 16)

\begin{tabular}{clcl}
\hline Assigned color & \multicolumn{1}{c}{ Status } & Final evaluation score & \multicolumn{1}{c}{ Explanation } \\
\hline Bronze & $\begin{array}{l}\text { (Conservation area is) minimally } \\
\text { managed }\end{array}$ & $<50$ percent & $\begin{array}{l}\text { Conservation area design has been } \\
\text { completed, and some management } \\
\text { activities have been executed as well, but } \\
\text { efforts to achieve management objectives } \\
\text { are still needed. }\end{array}$ \\
\hline Silver & $\begin{array}{l}\text { (Conservation area is) optimally } \\
\text { managed }\end{array}$ & $>50-85$ percent & $\begin{array}{l}\text { Management functions have been running } \\
\text { adaptively, and some management } \\
\text { objectives have been achieved. }\end{array}$ \\
\hline Gold & $\begin{array}{l}\text { (Conservation area is) managed } \\
\text { in sustainable fashion }\end{array}$ & $>85$ percent & $\begin{array}{l}\text { The benefits of management have been } \\
\text { enjoyed by communities with conservation } \\
\text { values being protected and conserved. }\end{array}$ \\
\hline
\end{tabular}

The guidelines do not measure and evaluate the achievement of the management actions against the MCA conservation goals and objectives in a straightforward manner. There is no framework to guide the relationship between the management actions' outputs and outcomes. Since the goals and objectives of MCAs in Indonesia are to protect and conserve biodiversity and use it sustainably (MMAF Ministerial Regulation 30/2010; Government Regulation 60/2007; MMAF Ministerial Regulation $17 / 2008)$, it is logical to use the biodiversity conservation outcomes in evaluating MCA achievements. Studies suggest that a framework that relates the outputs and outcomes to the associated indicators is essential to demonstrate how management actions successfully (or probably, on the contrary, unsuccessfully) maintain biodiversity in an MCA (Bennett and Dearden, 2014; Fox et al., 2014).

Furthermore, the guidelines use metrics, such as percentages, for results to indicate "achievements" of effective management. Such qualitative results have been proven inconclusive and do not reflect anything close to the achievement of management actions with respect to conservation goals and objectives (Addison et al., 2017). As long as these problems are not addressed, evaluations using the technical guidelines will remain pointless and unfair to the MCAs.

These findings suggest that the existing guidelines do not evaluate the anticipated achievement of the management actions in terms of conservation goals and objectives. Instead, they evaluate the achievements of less relevant nonmanagement action attributes that "mask" the management actions that must be taken to address threats faced by biodiversity and bio-resources in the MCAs. Since effective management and evaluation is critical for the MCA management unit and implementation of management actions, a focused and unbiased evaluation tool is definitely needed (Alvarez-Fernandez et al., 2020a, 2020b).
The evaluation of management effectiveness should be conducted according to the MCA management plan and based on how management actions have been carried out in the field, allowing the demonstration, measurement, and evaluation of meaningful and logical causal relationships between management actions and conservation outcomes. It is crucial then to have a guiding framework that shows such a relationship (Bennett and Dearden, 2014; Fox et al., 2014) with a detailed theory of change (Conservation Measures Partnership, 2020).

The evaluation of management effectiveness should be able to do the following: (i) evaluate whether the identified conservation problems, including sustainable utilization, are "correct" and relevant to the local context of the MCA and (ii) assess whether the strategies identified, selected, and implemented, including the zoning, are the most suitable interventions for addressing the problems. The result consists of conservation outcomes (for instance, whether the condition of the coral reefs has improved or is being maintained in the face of diving tourism use) that reflect the effectiveness of the interventions (i.e., strategies) in addressing the problems (i.e., human pressures and threats to biodiversity).

The approach to include the non-management action attributes in management effectiveness evaluation and the use of qualitative metrics to indicate management effectiveness should be gradually discarded. It is about time that quantitative metrics are employed to report the achievement of conservation outcomes (Addison et al., 2017) since they are more suitable for effective monitoring, evaluation, and reporting (MER) of conservation and the sustainable use of global coastal and marine biodiversity (Addison et al., 2018). Indonesian MCAs should start preparing management effectiveness evaluation reports that contribute directly to these efforts. 


\section{Conclusion}

In the Indonesian context, MCAs were established to protect, conserve, and utilize coastal and marine biodiversity sustainably (MMAF Ministerial Regulation 30/2010; Government Regulation 60/2007; MMAF Ministerial Regulation 17/2008). Since Indonesia is not immune to the paper parks problem, efforts have been made to make sure that the management of MCAs is carried out effectively to produce biodiversity conservation outcomes and support the sustainable utilization of biodiversity. In order to attain effective management, technical guidelines for evaluating the management effectiveness of MCAs in Indonesia were created in 2012 (DGMCSI Decree 44/2012) and amended in 2020 (DGMSM Decree 28/2020). The results indicate that there is a mismatch between what is being evaluated by the technical guidelines and what is expected to be achieved by each MCA and what should be evaluated for an MCA. It is obvious that the management plans were not conceived purposefully to support effective management. It seems that the mismatch contributes to why only a small percentage of MCAs have achieved "minimally managed" management status, as reported by Rusandi (2020). It can be concluded that the MCAs are not evaluable or eligible for management effectiveness evaluation.

\section{Acknowledgment}

The authors thank Dzimar Akbarur Rokhim Prakoso for preparing map of Figure 1. This research does not receive any specific grant from funding agencies in the public, commercial, or not-for-profit sectors.

\section{References}

Addison, P.F.E., Flander, L.B. \& Cook, C.N. 2017. Towards quantitative condition assessment of biodiversity outcomes: Insights from Australian marine protected areas. J. Environ. Manage., 198: 183-191. https://doi.org/10.1016/j.jen vman.2017.04.054

Addison, P.F.E., Collins, D.J., Trebilco, R., Howe, S., Bax, N., Hedge, P., Jones, G., Miloslavich, P., Roelfsema, C., Sams, M. \& Stuart-Smith, R.D. 2018. A new wave of marine evidence-based management: emerging challenges and solutions to transform monitoring, evaluating, and reporting. ICES J. Mar. Sci., 75(3): 941952. https://doi.org/10.1093/icesjms/fsx216

Alvarez-Fernandez, I., Freire, J. \& Sanchez-Carnero, N. 2020a. Low-quality management of Marine Protected Areas in the North-East Atlantic. Mar. Policy. 117: 103922. https://doi.org/10.1016/ j.marpol.2020.103922
Alvarez-Fernandez, I., Freire, J., Naya, I., Fernandez, N. \& Sanchez-Carnero, N. 2020b. Failures in the design and implementation of management plans of Marine Protected Areas: An empirical analysis for the North-east Atlantic Ocean. Ocean Coast. Manag., 192: 105178.https://doi. org/10.1016/j.ocecoaman.2020.105178

Bennett, N.J. \& Dearden, P., 2014. From measuring outcomes to providing inputs: Governance, management, and local development for more effective marine protected areas. Mar. Policy. 50: 96-110. https://doi.org/10.1016/j.marpol. 2014.05.005

Carter, E., Soemodinoto, A. \& White, A.T. 2011. Guidelines for Improving Management Effectiveness of Marine Protected Areas in Indonesia. The Nature Conservancy Indonesia Marine Program. Bali. 49 pp.

Conservation Measures Partnership. 2020. Open Standards for the Practice of Conservation version 4.0. Conservation Measures Partnership (www.conservationmeasures.org).

Davies, R. 2013. Planning Evaluability Assessment: A Synthesis of the Literature with Recommendations. Working Paper 40. UK Department of International Development. London. 48 pp.

Day, J.C., Laffoley, D. \& Zischka, K. 2015. Marine protected area management. In: Worboys, G.L., M. Lockwood, A. Kothari, S. Feary \& I. Pulsford (eds.). Protected Area Governance and Management. ANU Press. Canberra. p:609650.

Dunham, A., Dunham, J.S., Rubidge, E., lacarella, J.C. \& Metaxas, A. 2020. Contextualizing ecological performance: Rethinking monitoring in marine protected areas. Aquat. Conserv.: Mar. Freshw. Ecosyst., 30: 2004-2011. https://doi.org/10. 1002/aqc.3381

Fox, H.E., Holtzman, J.L., Haisfield, K.M., McNally, C.G., Cid, G.A., Mascia, M.B., Parks, J.E. \& Pomeroy, R.S. 2014. How Are Our MPAs Doing? Challenges in Assessing Global Patterns in Marine Protected Area Performance. Coast. Manag., 42(3): 207-226. https://doi.org/10. 1080/08920753.2014.904178

Gill, D.A., Mascia, M.B., Ahmadia, G.N., Glew, L., Lester, S.E., Barnes, M., Craigie, I., Darling, E.S., Free, C.M., Geldmann, J. \& Holst, S. 2017. Capacity shortfalls hinder the performance of marine protected areas globally. Nature. 543: 665-669. https://doi.org/10.1038/nature21708 
Government of Indonesia Regulation 60/2007 concerning Conservation of Fish Resources. (in the Indonesian Language)

Hockings, M., Stolton, S. \& Dudley, N. 2000. Evaluating Effectiveness: A Framework for Assessing the Management of Protected Areas. IUCN. Gland (Switzerland) \& Cambridge (UK). $121 \mathrm{pp}$.

Hockings, M., Stolton, S., Leverington, F., Dudley, N. \& Courrau, J. 2006. Evaluating effectiveness: a framework for assessing management effectiveness of protected areas, second edition. IUCN. Gland (Switzerland) \& Cambridge (UK). $105 \mathrm{pp}$

Kelleher, G. 1999. Guidelines for Marine Protected Areas. IUCN. Gland (Switzerland) \& Cambridge (UK). 107 pp.

OECD. 2002. Glossary of Key Terms in Evaluation and Results-Based Management. OECD Publications. $37 \mathrm{pp}$.

Pomeroy, R.S., Watson, L.M., Parks, J.E. \& Cid, G.A. 2005. How is your MPA doing? A methodology for evaluating the management effectiveness of marine protected areas. Ocean Coast. Manag., 48(7-8): 485-502. https://doi.org/10.1016/ j.ocecoaman.2005.05.004

Rapley, T. \& Rees, G. 2018. Collecting documents as data. In: Flick, U. (ed.). The SAGE Handbook of Qualitative Data Collections. Sage Publications Limited. London. p:378-391.

Rosales, R.M.P. 2018. SEAT: measuring socioeconomic benefits of marine protected areas.
Marine Policy. 92: 120-130. https://doi.org/ 10.1016/j.marpol.2018.02.026

Rusandi, A. 2020. Management of Conservation Areas. Presentation at Online Lesson Learnt 2020 "What is happening with marine conservation in Indonesia". Video conference, 20 May 2020. (in the Indonesian Language)

Salm, R.V., Clark, J. \& Siirila, E. 2000. Marine and Coastal Protected Areas: A guide for planners and managers. IUCN. Gland (Switzerland) \& Cambridge (UK). 370 pp.

Schreier, M. 2014. Qualitative content analysis. In: Flick, U. (ed.). The SAGE Handbook of Qualitative Data Analysis. Sage Publications Limited. London. p:170-183.

Soemodinoto, A., Yulianto, I., Kartawijaya, T., Herdiana, Y., Ningtias, P., Kassem, K.R. \& Andayani, N., 2018. Contribution of local governments to a national commitment of the Aichi Biodiversity Target 11: the case of West Nusa Tenggara Province, Indonesia. Biodiversity. 19: 72-80. https://doi.org/10. 1080/14888386.2018.1467790

Thomas, L. \& Middleton, J. 2003. Guidelines for Management Planning of Protected Areas. IUCN. Gland (Switzerland) \& Cambridge (UK). 79 pp.

White, A.T., Alino,P.A. \& Menesses, A. 2006. Creating and managing marine protected areas in the Philippines. Fisheries Improved for Sustainable Harvest (FISH) Project, Coastal Conservation and Education Foundation, Inc., and the University of the Philippines Marine Science Institute. Cebu City. Philippines. 83 pp. 